\title{
Comparative Evaluation of Water Deficit Tolerance Capacity of Extra-early and Early Maize Genotypes under Controlled Conditions
}

\author{
Y. A. Abayomi (Corresponding author) \\ Department of Agronomy, University of Ilorin \\ P.M.B. 1515, Ilorin, Nigeria
}

Tel: 234-806-055-3813 E-mail: yabayomi2007@yahoo.com

C. D. Awokola

Department of Agronomy, University of Ilorin

P.M.B. 1515, Ilorin, Nigeria

Tel: 234-803-217-9606 E-mail: awokola_damilola@yahoo.com

Z. O. Lawal

Department of Agronomy, University of Ilorin, P.M.B. 1515, Ilorin, Nigeria

E-mail: zainab.opeyemi@yahoo.com

Received: January 18, 2012 Accepted: February 16, 2012 Online Published: April 17, 2012

doi:10.5539/jas.v4n6p54 URL: http://dx.doi.org/10.5539/jas.v4n6p54

\begin{abstract}
Maize is an important staple food crop in Tropical Africa including Nigeria. However, the production of the crop is constrained by inadequate soil moisture resulting from erratic rainfall distribution. There is therefore the need to breed and select for drought tolerant genotypes for production especially in the southern Guinea savannah ecology responsible for over $60 \%$ of maize production in Nigeria. Controlled experiments using potted plants were therefore conducted during the dry periods between November 2007 and April 2008. The study evaluated moisture deficit tolerance capacity of two maize maturity groups, consisting of 15 extra-early and 12 early genotypes along with two local checks, subjected to two moisture levels $25 \%$ (stressed) and $100 \%$ (unstressed) soil available moisture) determined gravimetrically. Crop establishment parameters (\% germination and mean germination time (MGT), morphological growth parameters (number and area of leaves, plant height, flowering characteristics), physiological growth indices (leaf area index, crop growth rate, relative growth rate, net assimilation rate and leaf area ratio) were measured during growth. Yield components (harvest index, shelling percentage and number of kernels per cob) and grain yield were determined at harvest. The data were analyzed using the general model of ANOVA and significant means were separated by the Least Significance Difference (LSD) at 5\% probability level. The results showed that there were no appreciable differences between the two maturity groups for most measured parameters. However, across the two groups, crop establishment parameters, morpho-physiological growth parameters, yield components and grain yield were significantly reduced by soil moisture deficit, while flowering characteristics were significantly delayed by soil moisture stress with significant variable genotypic responses. Grain yield reduction due to water stress was significantly related to drought susceptibility index (DSI) of the genotypes in the two maturity groups. Conclusively, whereas extra-early genotypes showed good yield potentials but poor drought tolerance which suggested poor yield stability and therefore may not be suitable for the southern Guinea savanna (SGS) ecology in the event of severe stress. However, early genotypes, though showed lower yield potential, had good yield stability and hence are promising genotypes for the SGS ecology.
\end{abstract}

Keywords: Maize maturity group, Genotypes, Water deficit tolerance, Grain yield potential and stability, Drought susceptibility index 


\section{Introduction}

Maize (Zea mays L) is a staple food for a vast number of people around the world. Although the crop has its origin in a semi-arid area, is not a reliable crop for cultivation under dry land conditions with limited or erratic rainfall (Arnon, 1972). Maize is the third most important cereal crop after wheat (Triticum aestivum L) and rice (Oryza sativa $\mathrm{L}$ ) in terms of production in the world (IITA, 2009). Many studies have shown that maize has low drought tolerance capacity due to its high transpiration surface and poor root system. In Nigeria, notwithstanding the efforts of breeders and agronomists to develop high yielding cultivars (Fakorede, et al, 2001; Olakojo and Iken, 2001; Olaoye, et al, 2009) as well as improved production packages (Abayomi, 2004), the yield of maize in farmers' fields throughout the production regions, most especially the savannah ecologies of Nigeria is generally low averaging $<1.5 \mathrm{t} \mathrm{ha}^{-1}$. This low productivity has been attributed to low soil fertility and drought stress. Drought stress is a major abiotic factor that limits agricultural production (Nemeth, et al 2002; Chaves and Oliveria, 2004; Jaleel, et al, 2009; Golbashy, 2010), more importantly in the rain-fed areas of the world (Nikus, et al., 2004). This is probably due to inhibited cell expansion and reduced biomass production (Ashraf \& Mehmood, 1990). Frequent drought stress in the largely rain-fed agricultural system is therefore a major constraint limiting maize production in Nigeria.

One strategy to reduce the effect of water stress on crop yield is to use drought tolerant species and cultivars (Carrow, et al, 1990). This assertion was later supported by Siddique, et al. (2000), who reported that for the purpose of crop production, yield improvement and yield stability under water stress conditions, development of drought tolerant varieties is the best option. Crop plants are usually under stress at one time or another and the plant species able to withstand such stresses have great economic potential (Bibi, et al., 2010). Previous reports on drought tolerance in crops in literature show that variability in genotypic responses to water stress do occur in crops, for example in wheat (Moinuddin, et al. 2005), peanut (Upodhyaya, 2005), barley (Rizza, et al. 2004), soybean (Hufsteler, et al, 2007) and cowpea (Abayomi and Abidoye, 2009). These studies revealed that varieties/ genotypes in each species differed from each other in their responses to water stress conditions, suggesting that drought tolerance in such species may be improved through breeding.

When a large number of genotypes is available for screening against any stress condition, availability of a technique, which could rapidly and efficiently identify the varieties is important (Iqbal, et al, 2010). Although maize is susceptible to water deficit, there is a marked genotypic variations in root density, morphological and physiological characteristics in the crop, while Farhad, et al (2011) also reported that plant adaptation to drought involves both morphological and physiological alterations. It has been observed that water resources for agriculture are decreasing due to increase in demand for irrigation and other non-agricultural water uses (Bacon, 2004). As maize crop requires about 400 to $600 \mathrm{~mm}$ of water during its life cycle (Singh, 1991), water availability therefore imposes strong and recurring demand for screening maize genotypes for drought tolerance (Bohnert, et al., 1995). In their continual effort to improve maize production in the West and Central African sub-regions, the International Institute of Tropical Agriculture (IITA) and the West and Central Africa Maize Collaborative Research Network (WECAMAN) under the drought tolerant maize (DTMA) programme released some drought tolerant (DT) genotypes of different maturity groups for evaluation under rain-fed conditions. It was therefore the objective of the present study to screen some extra-early and early maize DT genotypes for moisture deficit tolerance under controlled conditions in a southern Guinea savannah ecology of Nigeria.

\section{Materials and Methods}

\subsection{Experimental Location, Design and Treatment Application}

The study was conducted during the dry periods between November 2007 and April 2008 at the crop pavilion of the Department of Agronomy, Faculty of Agriculture, University of Ilorin $\left(8^{\circ} 39^{\prime} \mathrm{N}, 4^{\circ} 35^{\prime} \mathrm{E}\right)$ in the southern Guinea savannah ecology of Nigeria using potted plants. The study designed as a factorial experiment, evaluated the responses of two maize maturity groups (consisting of 15 extra-early (60-75 days) 12 early (75-90 days) genotypes) obtained from the IITA, Ibadan and two local checks, Afo and DMR-STR-Y (Table 1) to two soil water levels (25\% (stressed) and 100\% (unstressed) soil available moisture determined gravimetrically (Kramer, 1983). The factorial combinations of the two factors were replicated three times. Ten litre capacity plastic pots perforated at the bottom were filled with $10 \mathrm{~kg}$ top soil and thereafter laid out according to the randomization plans. Prior to planting, each pot was moistened with enough water to achieve the desired soil moisture content ( 25 or $100 \%$ soil available moisture) following the randomization plans. Ten seeds of each genotype, treated with a fungicide, Apron Plus 50 DS (10\% Metalaxy, 6\% Carboxin and 14\% Ferothiocarp) were planted in each pot at a depth of $2.5 \mathrm{~cm}$. The resultant seedlings were later thinned to four per pot at two weeks after planting (WAP). Two of the seedlings were tagged for the collection of non-destructive data (plant height, number of 
leaves per plant, flowering traits), while the other two plants were harvested at 4 and 6 WAP for the collection of dry matter. Inorganic fertilizer (NPK 15-15-15) was applied at a rate equivalent to $80 \mathrm{~kg} \mathrm{~N} / \mathrm{ha}$ in two split applications at 2 and 6 WAP. Weed control inside and around the pots were done by regular hand pulling of emerging weeds.

\subsection{Data Collection}

Data collection included crop establishment obtained as seedling emergence counts from 3 to 9 days after planting (DAP) which were used to estimate percent germination and speed of germination as mean germination time (MGT in days) as described by Abayomi and Wright (1999). Morphological growth parameters (plant height, number of leaves and leaf area, tassel and silk appearances and pollen shed), physiological growth indices (crop growth rate, CGR; relative growth rate, RGR; net assimilation rate, NAR; leaf area ratio, LAR and leaf area index, LAI) were determined according to Hunts (1978) using leaf area and dry matter data collected at $4\left(\mathrm{t}_{1}\right)$ and $6\left(\mathrm{t}_{2}\right) \mathrm{WAP}$ as follows:

$\mathrm{NAR}=\left(\mathrm{W}_{2}-\mathrm{W}_{1}\right)\left(\ln \mathrm{A}_{2}-\ln \mathrm{A}_{1}\right) /\left(\mathrm{A}_{2}-\mathrm{A}_{1}\right)\left(\mathrm{t}_{2}-\mathrm{t}_{1}\right) ; \mathrm{CGR}=\left(\mathrm{W}_{2}-\mathrm{W}_{1}\right) /\left(\mathrm{t}_{2}-\mathrm{t}_{1}\right) ;$

$\mathrm{LAR}=\left(\mathrm{A}_{2}-\mathrm{A}_{1}\right)\left(\ln \mathrm{W}_{2}-\ln \mathrm{W}_{1}\right) /\left(\mathrm{W}_{2}-\mathrm{W}_{1}\right)\left(\ln \mathrm{A}_{2}-\ln \mathrm{A}_{1}\right) ; \mathrm{RGR}=\mathrm{NAR} X \mathrm{LAR} ; \mathrm{LAI}=$ leaf area/ ground area;

$\mathrm{W}_{1}$ and $\mathrm{W}_{2}=\mathrm{DM}$ weights at $\mathrm{t}_{1}$ and $\mathrm{t}_{2}$, while $\mathrm{A}_{1}$ and $\mathrm{A}_{2}$ are the respective leaf area.

Yield components (harvest index $(\mathrm{HI})=$ grain yield/biological yield; shelling percentage $(\mathrm{SP})=$ grain weight $/ \mathrm{cob}$ weight $\mathrm{x} 100$ and number of kernels per cob) and grain yield were determined at harvest. To assess the drought tolerance of genotypes, percent yield reduction (PRED) was calculated as PRED $=(\mathrm{Yp}-\mathrm{Ys}) / \mathrm{Yp} \times 100$, while drought susceptibility index (DSI) was estimated using the expression $(1-\mathrm{Ys} / \mathrm{Yp}) / \mathrm{SI}$, where $\mathrm{Ys}=$ grain yield under stress; $\mathrm{Yp}=$ yield at normal soil moisture; $\mathrm{SI}=$ stress intensity $=1$ - mean yield of all genotypes under stress/mean yield of all genotypes at normal soil moisture, as described by Golabadi, et al (2006).

\subsection{Statistical Analysis}

All data were analyzed using the general model of the Analysis of Variance (ANOVA) with Genstat Discovery 3 and significant means were separated by the Least Significant Difference (LSD) at 5\% probability level.

\section{Results}

\subsection{Effects Genotypes and Moisture Deficit on Crop Establishment and Morphological Growth Parameters}

The effect of maturity group was significant for percent germination under moisture deficit in favour of the extra-early genotypes, while there was no significantly difference in the percent germination of the two groups under normal soil moisture. However, MGT was similar for the two maturity groups under both soil moisture conditions (Table 2). Germination percent was higher with the extra-early genotypes, while MGT was lower with the group. Across the genotypes of the two groups, the effect of soil moisture levels was not significant for the two crop establishment parameters. There were significant variations among genotypes of each maturity group for crop establishment parameters. Among the extra-early genotypes, percent germination was highest with G11 and least with G2, while the highest and the lowest germination percent were obtained with G17 and G26 respectively among the early genotypes. Overall, germination was faster but slightly higher under normal soil moisture condition than under soil moisture deficit. Significant genotype $\mathrm{x}$ moisture level observed for the percent germination revealed that while moisture level had no significant effect on germination percent of most genotypes across the two maturity groups, the parameter was significantly reduced in G27 and increased in G28 by soil moisture deficit.

Results in Table 3 show that the effect of maturity group was significant for the morphological growth parameters. The number of leaves per plant and leaf area were higher with the extra-early genotypes, while the plant height was higher with the early genotypes. The effect of soil moisture deficit was significant for the plant height and leaf area, but not for the number of leaves per plant. The number of leaves per plant and consequently leaf area were significantly higher in the extra-early than in the early genotypes. However, the extra-early genotypes were significantly shorter than the early genotypes. The number of leaves was not significantly different between the well-watered and the stressed plants, even though the leaf area was significantly higher in the well-watered plants. Plant height was also significantly higher in the well-watered plants than in the stressed plants. The interactive effects of maturity group x soil moisture deficit was significant for the number of leaves per plant and leaf area, but not significant for the plant height. Results in Table 3 also show that the plant height and leaf area were higher with the well-watered than in the stressed plants.

The number of leaves and plant height were not significantly different among genotypes, while the LA varied significantly among them. Leaf area was significantly highest $\left(3232 \mathrm{~cm}^{2}\right)$ with an extra-early genotype, G5, and 
lowest $\left(1241 \mathrm{~cm}^{2}\right)$ with $\mathrm{G} 24$, an early genotype, which value was however not significantly lower than the values obtained for G17, G18, G20, G22 and G25 (Table 3).

Both the tassel and silk emergences were not significantly influenced by the maturity group, but the anthesis and ASI differed significantly between the two groups (Table 4). While the anthesis was significantly earlier in the extra-early group, ASI was significantly smaller with the early group. Table 4 also shows that all flowering traits were significantly delayed by soil moisture deficit. The genotypes in the two groups varied significantly for most flowering traits, except ASI which values were not significantly different among genotypes of the two groups. Significant maturity group $\mathrm{x}$ moisture deficit effect observed for anthesis, silk appearance and ASI revealed that anthesis date was significantly longer with the early than the extra-early genotypes in well-watered plants, while there were no appreciable differences between the groups in stressed plants. Silk appearance was significantly delayed by soil moisture deficit in the extra-early genotypes, while the treatment has no significant effect on silk appearance of the early genotypes. Consequently, ASI was significantly increased by moisture deficit in extra-early genotypes, while there were no significant differences between the well-watered and stressed early maize genotypes. Significant moisture level x genotype effect obtained for the LA revealed that while LA was not significantly influenced in 5 genotypes, G10 (extra-early), G18, G22, G23 and G24 (early), the parameter was significantly reduced by soil moisture deficit in all other genotypes (Table 4).

\subsection{Effects of Maize Genotype and Soil Moisture Deficit on Physiological Growth Indices}

The two maturity groups were not significantly different for all physiological growth traits (Table 5), with the exception of LAI which was significantly higher in the extra-early than in the early genotypes (Table 6). However, all indices varied significantly $(\mathrm{p}<0.001)$ among genotypes and were significantly $(\mathrm{p}<0.01)$ reduced by soil moisture deficit, except RGR which values were similar for all genotypes and was not significantly ( $p>0.05)$ influenced by soil moisture (Table 5) and LAR which was significantly increased by moisture deficit (Table 6). Significant maturity group $\mathrm{x}$ moisture deficit for CGR showed that while the extra-early had significantly higher CGR value than the early genotypes in well watered condition, the earlier group showed significantly lower CGR than the later under moisture deficit condition (Table 5). Significant moisture level x genotype effect for CGR showed that moisture deficit significantly reduced CGR in most genotypes of the two maturity groups, except in 2 extra-early (G4, G10) and 7 early (G18, G19, G21, G22, G23, G25 and G26) genotypes which were not significantly influenced by soil moisture deficit (Table 5). Similar significant moisture level x genotype effect for LAR revealed that while LAR was significantly increased by soil moisture deficit in 5 extra-early (G2, G3, G5, G9 and G15) genotypes and 3 early (G18, G20 and G28), the parameter was not significantly influenced by soil moisture level in other genotypes (Table 6).

\subsection{Effects Genotype and Soil Moisture Deficit on Yield Components and Grain Yield}

The yield components of genotypes under normal and moisture deficit conditions are presented in Table 7, while grain yields under both moisture conditions, yield reduction due to moisture deficit and drought susceptibility index of genotypes are presented in Table 8. The harvest index was significantly $(p<0.05)$ higher in the extra-early than in the early genotypes, while the shelling percent and number of kernels per cob were not significantly different for the two maturity groups (Table 7). All yield components were significantly reduced by soil moisture deficit across the genotypes of the two maturity groups. The values of HI and SP significantly varied among the genotypes of each maturity group, which however showed similar values for the number of kernels per cob (Table 7). Significant moisture level x genotype effect showed that HI was significantly reduced by moisture deficit in 7 extra-early (G8, G12, G13, 14, G15 and check 1, G16) and 2 early (G20 and check 2, G29) genotypes, while the parameter was not significantly affected by moisture level in other genotypes. Grain yield across moisture levels was insignificantly higher in the extra-early than in the early genotypes (Table 8). Table 8 also shows that grain yield was highest with G10 and lowest with G1 under moisture deficit. However, with adequate soil moisture, grain yield was highest with G8 and still lowest with G1. Significant maturity group $\mathrm{x}$ moisture deficit effect obtained for grain yield showed that grain yield was significantly higher in the extra-early than in the early genotypes when plants were well-watered, while there were no significant difference in grain yield of the two groups under soil moisture deficit (Table 8). Among the genotypes, percent grain yield reduction was highest with an extra-early (G8) and lowest with G22, an early genotype (Table 8 ). The results on percent grain yield reduction were similar to those of drought susceptibility index (DSI) which showed that DSI was higher with extra-early genotypes than in the early genotypes, and highest and lowest with G8 and G22 respectively, hence a significant positive relationships between the two parameters and / or negative relationships between grain yield under stress and drought tolerance index (Figure 1). 


\section{Discussion}

Speed and quantum of germination are important prerequisites for the success of stand establishment in crop plants. Proper germination of planted seeds, the rate and degree of the subsequent seedling establishment are of great importance in determining both yield and time of maturity (Brigg and Aytenfisu, 1979). However, soil moisture deficit affects seed germination (Abayomi and Wright, 1999; Etejere, 2004), while the effects of moisture stress on seed germination had been shown to be crop species and genotype dependent (Abayomi, 1992). The results of the present study showed that germination percent and speed of germination (MGT) were significantly reduced under moisture deficit condition in all maize genotypes belonging to the two maturity groups evaluated. Significant maturity group x moisture deficit effect showed no significant differences in germination percent of the two maturity groups when adequately watered, while the extra-early genotypes germinated significantly better than the early genotypes when they were water-stressed. These results are in line with the early reports (Smith and Hoveland, 1986; Abayomi and Saliu, 1997; Abayomi and Wright, 1999) which showed that water stress affected germination by delaying its onset, slowing its rate and by decreasing the final germination percentage. The results also showed significant differences in germination between the two maturity groups and within the genotypes in consonance with the reports of Ashraf and Abu-Shakra (1978) who showed that the ability of seeds to germinate at low soil moisture was dependent on crop species and genotypes. The speed of germination was also significantly reduced (high MGT) by soil moisture deficit in the present study. This was similar to the reports of earlier workers (Abayomi and Mobolaji, 1995; Abayomi and Saliu, 1997; Abayomi and Wright, 1999; Smith, et al., 1989) who showed significant increase in MGT due to low available soil moisture. The decrease in germination rate as shown by high MGT with soil moisture deficit observed in the present study may be due to reduced water uptake by the germinating seeds (Abayomi, 1992). The overall results of germination tolerance of soil moisture stress show that crop establishment was better with extra-early than the early genotypes. Among the genotypes, G11 (extra-early) showed the best establishment, while G29 (local check 2) show the least in terms of germination percentage and speed of germination (MGT).

Morphological growth characters of number of leaves per plant, leaf area and plant height were significantly reduced by soil moisture deficit. The reduction in leaf area as a result of water deficit is attributable to decreased rate of leaf initiation and expansion / and or increased rate of leaf senescence and leaf shedding (Legg, et al., 1979). Nesmith and Rochie (1992) and Fortis and Edward (1995) have reported that water deficit reduced leaf development and decreased leaf area expansion. The importance of the number of leaves to grain yield has been shown by Benti and Ranson (1993) who reported that grain yield is directly proportional to the number of leaves removed. The decrease in plant height by soil moisture deficit as observed in the study was in line with the report of Gavloski, et al. (1992) who observed that there was a decrease in maize plant height following the withdrawal of water from one or more section of the root system. The importance of plant height as a yield predictor has been shown by Abayomi (1992) and Hadjichristodoulou (1987) had earlier suggested that variations in plant height may become one of the causes of variation in crop yield. This suggests that genotype that can maintain good plant height under stress are likely to give good grain yield in line with the results of this study which showed that when water stress reduced plant height by $37.4 \%$, grain yield was reduced by $59.28 \%$ in the extra-early genotypes. However, in the early genotypes, a reduction of $24.06 \%$ in plant height by moisture deficit resulted in a decrease of only $39.46 \%$ grain yield. Among the genotypes, two early genotypes (G21 and G24) showed good heights and hence good grain yields under stress.

The results of the effect of water stress on flowering traits showed that inadequate soil moisture significantly delayed tassel and silk appearance, anthesis and hence increased ASI. Flowering traits in maize have been shown to be significantly delayed under severe drought (Edmeades, et al., 1997). Similarly, Herrero and Johnson (1981) also reported that water stress during the reproductive period can increase the interval from silking to pollen shed which shortened the grain filling period. The results of this study were also in line with the observation of Mckenzie (2006) who reported that water stress during flowering causes several changes in plant development including delay in silk emergence and pollen shed, resulting in synchronous pollination, decreased kernel weight, delay in physiological maturity and a decrease in final yield. Edmeades, et al. (2000) also reported that water stress slows ear growth in relation to tassel growth resulting in an increase in anthesis to silking interval (ASI).

The results of the present study also show that most physiological growth indices measured were significantly reduced by inadequate soil moisture content across the genotypes. The reduction in net assimilation rate (NAR) was in agreement with the report of Boyle, et al (1991) who showed that low seed yield at low water potential can be accounted for by lack of assimilate supply at flowering. The results also showed that soil moisture stress reduced leaf area index (LAI), suggesting reduction in photosynthesis. It has been observed that photosynthesis can be reduced by water stress through reduction in leaf area, stomatal closure and decrease in the efficiency of 
carbon fixation process (Ludlow, 1975). Soil moisture deficit reduced all yield components and grain yield in maize genotypes across the two maturity groups. Girma, et al (2005) have reported reduction in HI as a result of moisture stress. Other workers have also reported reduction in yield components and grain yield due to water stress. O'Neil, et al (2004) reported that water stress during grain fill period caused decrease in kernel weight, earlier physiological maturity and decrease in final yield. Percent grain yield reduction due to soil moisture deficit was observed to be positively related to drought susceptibility index (Figure 1) in line with the report of Rizza, et al. (2004) who showed significant negative relationship between grain yield and water stress index of barley (Hordeum vulgare, L) genotypes. A lower grain yield reduction under stress suggests a higher yield stability which is more important than breeding and selection for absolute high yield under stress.

According to Roland (1993), drought resistant genotypes are known for their higher yields under conditions of limited and uncertain rainfall. The results of the present study show that genotypes G2, G9, G10, G21 and G25 had higher grain yields under stress condition, suggesting that they are more water stress tolerant than the other genotypes. The focus of varietal response evaluation to environmental stress is to identify superior genotypes that perform relatively well under stress and could be used to replace the existing genotypes and / or as sources of genes for the production of inbred lines aimed at the development of stress tolerant genotypes (Olaoye, 2009). The above identified genotypes are therefore promising for the southern Guinea savannah and could replace the two local checks, Afo (G2, G9, and G10) and DMR-SRT-Y (G21 and G25), as well as being sources of genes for breeding programme for drought tolerant maize cultivars in the zone. However, it has been suggested that in an environment prone to severe drought conditions like the Guinea savannah ecology (SGS), the most suitable genotypes should maintain high yield under both favourable and stress conditions (Rizza, et al., 2004). Considering the results of the 29 genotypes evaluated in the present study, an extra-early genotype, G10, ranked best under stress and no stress conditions and may therefore be the best genotype for the SGS ecology. Although reduced with inadequate soil moisture, its yield was superior under both conditions. The results further show that five genotypes (G8, G11, G3 and G5, all extra-early genotypes), had higher yield potentials under favourable soil moisture condition, but were highly susceptible to drought stress. There is some agreement that a high yield potential is advantageous under moderate stress, while high drought tolerance may be more useful under severe stress (Voltas, et al, 1999; Panthywan, et al, 2002)., thereby suggesting that these five genotypes may not be suitable for the SGS ecology in the event of severe stress. However, three early genotypes (G22, G23 and G19), with lower yield potentials under favourable moisture condition, showed lower yield reductions under stress (Table 8), thereby suggesting good yield stabilities and are therefore promising candidates for the ecology. An extra-early genotype, G1, showed poor yield potential with adequate soil moisture and dismally low drought tolerance, is neither good for cultivation nor as a source of genes for drought tolerance improvement programme for the ecology.

Conclusively, two extra-early genotypes (G2 and G10) and two early genotypes (G21 and G25), which showed both high yield potentials under favourable moisture condition and good drought tolerance under moisture deficit, are promising as DT genotypes for the SGS ecology and can therefore replace Afo and DMR-SRT-Y (local checks), and as well serve as sources of genes for the improvement of three extra-early genotypes (G8, G11 and G16) with high yield potentials under favourable moisture condition, but low stability under moisture deficit; and three early genotypes (G19, G22 and G23) which look promising as DT genotypes, but showed low yield potentials under favourable moisture condition. Hybridization of these identified ten genotypes may result in the production of better DT genotypes well suited to the SGS ecology.

\section{References}

Abayomi, Y. A. (1992). Comparative effects of water stress on wheat and sugar beet. Ph.D. Thesis (pp. 522), University of Wales, Bangor, UK.

Abayomi, Y. A. (2004). Interactive effects of water stress and nitrogen application on growth and yield of hybrid maize varieties. Plant Scientists, 4(4), 66-80.

Abayomi, Y. A., \& Abidoye, T. O. (2009). Evaluation of cowpea genotypes for soil moisture stress tolerance under screen house conditions. African Journal of Plant Science, 3(10), 229-237. Online at http://www.academicjournals.org/AJPS

Abayomi, Y. A., \& Saliu, L. O. (1997). Emergence and seedling vigour responses to simulated sub-optimal moisture conditions in twelve open pollinated maize (Zea mays L) varieties. Biosciences Research Communications, 9(1), 21-28.

Abayomi, Y. A., \& Wright, D. (1999a). Osmotic potential and temperature effects on germination of spring wheat (Triticum aestivum L.) genotypes. Tropical Agriculture, (Trinidad), 76(2), 120-125. 
Arnon, I. (1972). Crop production in dry regions. Leonard Hill, London.

Ashraf C. M., \& Abu-Shakra, S. (1978). Wheat seed germination under low temperature and moisture stress. Agronomy Journal, 70, 135-139. http://dx.doi.org/10.2134/agronj1978.00021962007000010032x

Ashraf, M., \& Mehmood, S. (1990). Response of four Brassica species drought stress. Environ. Expt. Bot. 30:93-110. http://dx.doi.org/10.1016/0098-8472(90)90013-T

Bacon, M. A. (2004). Water Use Efficiency in Plant Biology. Blackwell Publishing, Oxford, UK.

Benti, T., \& Ranson, J. K. (1995). Quantitative and physiological traits in maize associated with different levels of moisture deficit and leaf defoliation in Ethiopia. IAR pg. 74-85.

Bibi, A., Sadaqat, H. A., Akram, H. M., \& Mohammed, M. I. (2010). Physiological Markers for screening sorghum (Sorghum bicolor) germplasm under water stress condition. Int. J. Agric. Biol., 12, 451-455. Online: http://www.fspublishers.org

Bohnert, H. J., Nelson, D. E., \& Jensen, R. G. (1995). Adaptations to environmental stresses. Plant Cell, 7 , 1099-1111.

Boyle, M. G., Boyer, J. S., \& Morgan, P. W. (1991). Stem infusion of liquid culture medium prevents reproductive failure in maize at low water potential. Crop Science, 31, 1246-1252. http://dx.doi.org/10.2135/cropsci1991.0011183X003100050033x

Brigg, K. G., \& Aytenfisu, A. (1979). The effects of seeding rate, seeding time and locate on grain yield, maturity, protein percentage and protein yield of some spring wheat in Central Alberta. Canadian Journal of Plant Science, 59, 1129-1146.

Carrow, R. N., Shearman, R. C., \& Watson, J. R. (1990). Turfgrass. In irrigation of agricultural crops Agon. Monogr(pp. 889-919). 30, ASA, CSSA and ASSA (ed. B.A. Stewart and D.R Nielson). Madison, W1. Centre for ClimateChange Research, School of Environmental Sciences, University of Change Scenarios for United Kingdom. The UKCIP02 Scientific Report, Tyndall.

Chaves, M. M., \& Oliveria, M. M. (2004). Mechanisms underlying plant resilience to water deficits: prospects of water-saving agriculture. J. Exp. Bot., 55, 2365-2384. http://dx.doi.org/10.1093/jxb/erh269

Edmeades, G. O., Bazinger, M., Chapman, S. C., Ribault, J. M., \& Bolanos, J. (1997). Recent advances in breeding for drought tolerance in maize. Pp. 22-41 in Bad-Apraku, B., M.O. Akoroda, M. Ouedraogo and F.M. Quin (eds). Contribution to food self-sufficiency: Maize research and Development in West Africa. Proceedings of a Regional Maize Workshop, 29 May - 2 June, 1995, IITA Cotonou, Benin Republic.

Edmeades, G. O., Bolanos, J., Elings, A., Banzoger, M., \& Westgate, M. E. (2000). The role and regulation of the anthesis-silk interval. In M.E. Westgate and K.J. Boote (eds.) Physiology and Modeling Kernel set in maize. CSSA Special Publication, 29, 43-73.

Etejere, E. O. (2004). The seed sower and the germination dilemma. $73^{\text {rd }}$ Inaugural Lecture, University of Ilorin. Library and Publication Committee, 33.

Farhad, W., Cheema, M. A., Saleem, M. F., \& Saqib, M. (2011). Evaluation of drought tolerant and sensitive maize hybrids. Int. J. Agric. Biol., 13(4), 523-528. Online: http://www.fspublishers.org

Fakorede, M. A. B., Badu-Apraku, B., Coulibaly, O., \& Fajemisin, J. M. (2001). Impact, challenges and prospects of maize research and development in West and Central Africa. Proceedings of a Regional Maize Workshop (pp. 31-58), IITA Cotonou, Benin Republic, 4-7 May 1999 WECAMAN/IITA (EDS. Badu-Apraku, M.A.B. Fakorede, M.Ouedraogo and R.J. Carsky).

Fortis, M. C., \& Edwards, M. (1995). Leaf area of strip intercropped corn in dry and normal growing seasons. Agronomy Journal, 87, 569-574. http://dx.doi.org/10.2134/agronj1995.00021962008700030029x

Gavloski, G. E., Whitefield G. H., \& Ellis, G. R. (1992). Effect of restricted watering on sap flow and growth in corn (Zea mays L). Plant Science, 72, 361-368.

Girma, A., Teshale, A., Hussen, H., Tewedro, M., \& AbdulRahman, M. (2005). Participatory selection of drought tolerant maize varieties using mother and baby methodology: A case study in the semi arid zones of the Central Rift Valley of Ethiopia.

Golabadi, M., Arzani, A., \& Mirmohammadi Malbody, S. A. M. (2006). Assessment of drought tolerance in segregating populatios in Durum wheat. African Journal of Agricultural Research, 1(5), 162-171. 
Golbashy, M., Ebrahimi, M., Khorasani, S. K., \& Choukan, R. (2010). Evaluation of drought tolerance of some corn (Zea mays L) hybrids in Iran. African J. Agric. Res., 5, 2714-2719.

Hadjichristodoulou, A. (1987). Stability performance of of cereals in low rainfall area as related to adaptive traits. In Drought Tolerance in winter cereals (ed. J.P. Strivastava, E. Porceddu, E. Acevedo and S. Varma), pp 191-200. New York, Wiley Interscience for ICARDA.

Herrero, M. P., \& Johnson, R. R. (1981). Drought stress and its effects on maize reproductive systems. Crop Science, 21, 105-110. http://dx.doi.org/10.2135/cropsci1981.0011183X002100010029x

Hufsteler, E. V., Boerma, H. R., Carter, T. E., \& Earl, H. J. (2007). Genotypic variation for three physiological traits affecting drought tolerance in soybean. Crop Science, 47, 25-35. http://dx.doi.org/10.2135/cropsci2006.04.0243

Hunt, R. (1978). Plant growth analysis studies.: The rationale behind the use of the fitted function. Ann. Bot. N. S., 43, 245-249.

IITA (International Institute of Tropical Agriculture). (2009). Gereals and Legumes Systems. Available online: http://old.iita.org/cms/details/maize_projects_deails.aspx?zoneid=63\&articlid=273, $21^{\text {st }}$ September.2009, p.1.

Iqbal, K., Azhar, F. M., Khan, L. A., \& Ullah, E. (2010). Assessment of cotton (Gossypium Hirsuthum) germplasmunder water stress condition. Int. J. Agric. Biol., 11, 251-255. http://www.fspublishers.org

Jalee, C. A., Manivannan, P., Wahid, A., Farooq, M., Al-Juburi, H. J., Somasundram, R., \& Panneerselvam, R. (2009). Drought stress in plants: A review of morphological characteristics and pigments composition. Int. J. Agric. Biol., 11, 100-105.

Krammer, P. J. (1983). Water Relations of Plants. Academic Press Inc.: New York.

Legg, B. I. W., Lawlor, D., \& Parkinson, K. J. (1979). The effects of drought on barley growth measurement showing the relative importance of leaf area and photosynthetic rate. Journal of Agriculture Science, 92, 703-716. http://dx.doi.org/10.1017/S0021859600053958

Ludlow, M. M. (1975). Effects of water stress on the decline of leaf net photosynthesis with age: In Environmental and Biological Control of Photosynthesis (pp.123-134). (ed. R. Mcelle). http://dx.doi.org/10.1007/978-94-010-1957-6_13

McKezic, A. (2006). Water stress timing effects on hybrid maize. Master of Science/Agronomy. Creative Component, New York 1:1

Moinuddin, R., Fischer, A., Sayre, K. D., \& Reynoids, M. P. (2005). Osmotic adjustment in wheat in relation to grain yield under water deficit environments. Agronomy Journal, 97, 1062-1071. http://dx.doi.org/10.2134/agronj2004.0152

Nemeth, M., Janda, T., Horvath, E., Paldi, E., \& Szalai, G. (2002). Exogenous salicyclic acid increase polyamine content but may decrease drought tolerance in maize. Plant Science, 162, 569-574. http://dx.doi.org/10.1016/S0168-9452(01)00593-3

Nesmeth, D. S., \& Rochie, J. T. (1992). Short and Long-term responses of corn to a pre-anthesis soil water deficit. Agronomy Journal, 84, 107-113. http://dx.doi.org/10.2134/agronj1992.00021962008400010021x

Nikus, O., Turk, M. A., \& Al-Tawaha, A. M. (2004). Yield responses of sorghum (Sorghum bicolor, L) to manure supplemented with phosphate fertilizer under semi-arid Mediterranean conditions. Int. J. Agric. Biol., 6, 889-893.

Olakojo, S. A., \& Iken, J. E. (2001). Yield performance and stability in some improved maize (Zea mays L) varieties. Moor J. Agric. Res., 2, 21-24.

Olaoye, G. (2009). Screening for moisture deficit tolerance in four maize (Zea may L) populations derived from drought tolerant inbred x adapted cultivar crosses. Journal of Tropical and Subtropical Agroecosystems, 10, 237-251.

Olaoye, G., Bello, O. B., Abubakar, A. Y., Olayiwola, L. S., \& Adesina, A. O. (2009). Analyses of moisture deficit grain yield loss in drought tolerant maize (Zea mays L) germplasm accessions and its relationship with field performance. African Journal of Biotechnology, 8(14), 3229-3238. Online: http://www.academicjournals.org/AJB 
O’Neil, P. M., Shanahan, J. F., Scheper, J. S., \& Cadwell, B. (2004). Agronomic responses of corn hybrids from different ears to deficit and adequate water levels of water and nitrogen. Agronomy Journal, 96, 1660-1667. http://dx.doi.org/10.2134/agronj2004.1660

Panthuwan, G., Fukai, S., Cooper, M., Rajatasereekul, S., \& O’Toole, J. C. (2002). Yield response of rice (Oryza sativa L) genotypes to different types of drought under rainfed lowlands. Part 1: Grain yield and yield components. Field Crop Res., 73, 153-168. http://dx.doi.org/10.1016/S0378-4290(01)00187-3

Rizza, F., Badeck, W., Cattivelli, L., Lidestri, O., Di Fonzo, N., \& Stanca, A. M. (2004). Use of a water stress index to identifybarley genotypes adapted to rainfed and irrigation conditions. Crop Science, 44, $2127-2137$. http://dx.doi.org/10.2135/cropsci2004.2127

Rowland, J. R. (1993). Dry land Farming in Africa. Macmillan Education Ltd.

Siddique, M. R. B., Hamid, A., \& M. S. (2000). Drought stress effects on water relation of wheat. Bot. Bull. Acad. Sin, 41(1), 35-39.

Smith, R. L., \& Hoveland, C. J. (1986). Effect of temperature and water stress on seed germination and seedling emergence of pearl millet: In Agronomy Abstract. AJA, Maidson, W1 94

Smith, R. L., Hoveland, C. J., \& Hanna, W. W. (1989). Water stress ans temperature in relation to seed germination of pearl millet and sorghum. Agronomy Journal, 81, $303-305$. http://dx.doi.org/10.2134/agronj1989.00021962008100020032x

Upadhyaya, H. D. (2005). Variability for drought resistance related traits in the mini core collection of peanut. Crop Science, 45, 1432-1440. http://dx.doi.org/10.2135/cropsci2004.0389

Voltas, J., Romagosa, I., Lafarga, A., Armesto, A. P., Sombrero, A., \& Araus, J. L. (1999). Genotype by environment interaction for grain yield and carbon isotope discrimination of barley in Mediterranean Spain. Aust. J. Agric. Res., 50, 1263-1271. http://dx.doi.org/10.1071/AR98137 
Table 1. The evaluated extra-early, early and local maize genotypes for responses to soil moisture deficit at Ilorin, southern Guinea savanna, Nigeria

\begin{tabular}{|c|c|}
\hline Code Number & Genotype \\
\hline \multicolumn{2}{|c|}{ Exra-early genotypes } \\
\hline G1 & TZEE-W POP STR $C_{4}$ \\
\hline G2 & TZEE-Y POP STR C 4 \\
\hline G3 & 2000 Syn EE-W QPM C 0 \\
\hline G4 & TZEE-W POP SYR $C_{0} S_{6} \operatorname{lnb} \times 9071$ \\
\hline G5 & TZEE-W POP STR QPM C $C_{0}$ \\
\hline G6 & TZEE-YSR BC 1 X 9450 STR $S_{6} \operatorname{lnb} 10 B \times 4000$ \\
\hline G7 & 2000 Syn EE-W \\
\hline G8 & TZEE-Y POP STR QPM C 0 \\
\hline G9 & 99 TZEF-Y STR QPM C 0 \\
\hline G10 & EV 99 QPM \\
\hline G11 & TZEE-W POP x LD S 6 (Set A1) \\
\hline G12 & TZEE-W POP x LD S 6 (Set A2) \\
\hline G13 & 99 TZEE-Y STR $C_{0}$ \\
\hline G14 & 2004 TZEE-Y POP STR C 4 \\
\hline G15 & 2004 TZEE-W POP STR C 4 \\
\hline G16 & Afo (Check 1) \\
\hline \multicolumn{2}{|c|}{ Early Genotypes } \\
\hline G17 & EV DT-W 99 STR $C_{0}$ \\
\hline G18 & EV DT-97 STR $C_{1}$ \\
\hline G19 & EV DT-W 99 STR QPM C 0 \\
\hline G20 & TZE-Y DT STR $\mathrm{C}_{4}$ \\
\hline G21 & TZE-Y DT STR QRM C ${ }_{0}$ \\
\hline G22 & TZE-W DT STR $C_{4}$ \\
\hline G23 & AC 90 Pool 16 DT STR \\
\hline G24 & TZE Comp 3 DT $\mathrm{C}_{1} \mathrm{~F}_{2}$ \\
\hline G25 & TZE Comp 3 DT $\mathrm{C}_{2} \mathrm{~F}_{2}$ \\
\hline G26 & EV DT-Y 2000 STR QPM C \\
\hline G27 & EV DT-Y 2000 STR C 0 \\
\hline G28 & Pool 18-SR/AK94-DMRESR-Y \\
\hline G29 & DMR-SRT-Y (Check 2) \\
\hline
\end{tabular}


Table 2. Crop establishment of some maize genotypes under moisture deficit and irrigated conditions

\begin{tabular}{|c|c|c|c|c|c|c|}
\hline \multirow{2}{*}{$\begin{array}{l}\text { Treatment } \\
\text { Genotype }\end{array}$} & \multicolumn{3}{|c|}{ Percent Germination (\%) } & \multicolumn{3}{|c|}{ Mean Germination Time (MGT) (days) } \\
\hline & Stressed & Unstressed & Mean & Stressed & Unstressed & Mean \\
\hline \multicolumn{7}{|l|}{ Extra-early } \\
\hline G1 & 90.0 & 96.7 & $93.3 a b$ & 4.5 & 4.3 & 4.4def \\
\hline $\mathrm{G} 2$ & 16.7 & 43.3 & $30.0 \mathrm{mno}$ & 8.8 & 7.0 & $7.9 a$ \\
\hline G3 & 53.3 & 73.3 & $63.3 d-h$ & 5.6 & 4.1 & $4.8 \mathrm{c}-\mathrm{f}$ \\
\hline G4 & 50 & 60 & $55.0 f-k$ & 6.5 & 5.0 & $5.7 \mathrm{bc}$ \\
\hline G5 & 36.7 & 46.7 & 41.7i-n & 4.4 & 4.5 & $4.5 c-f$ \\
\hline G6 & 46.7 & 70 & $58.3 e-j$ & 5.8 & 4.7 & $5.3 b c d$ \\
\hline G7 & 43.3 & 70 & $56.7 f-k$ & 5.3 & 4.2 & $4.7 c-f$ \\
\hline G8 & 46.7 & 66.7 & $56.7 f-k$ & 5.1 & 3.8 & $4.5 c-f$ \\
\hline G9 & 43.3 & 60 & $51.7 \mathrm{~g}-1$ & 5.5 & 4.4 & 5.0cde \\
\hline G10 & 80 & 83.3 & $81.7 a-d$ & 4.3 & 3.7 & 4.0ef \\
\hline G11 & 93.3 & 100 & $96.7 a$ & 4.4 & 3.6 & 4.0ef \\
\hline G12 & 70 & 86.7 & 78.3a-e & 3.9 & 3.5 & $3.7 f$ \\
\hline G13 & 86.7 & 90 & 88.3abc & 3.8 & 3.6 & $3.7 f$ \\
\hline G14 & 83.3 & 96.7 & $90.0 \mathrm{abc}$ & 4.4 & 3.6 & 4.0ef \\
\hline G15 & 83 & 90 & 86.7abc & 5 & 3.5 & 4.3def \\
\hline G16 (check 1) & 23.3 & 40 & 31.71-o & 4.7 & 4.4 & $4.6 c-f$ \\
\hline Group Mean & $70.8 \mathrm{~A}$ & $61.5 \mathrm{~A}$ & & $5.1 \mathrm{~A}$ & $4.5 \mathrm{~A}$ & \\
\hline \multicolumn{7}{|l|}{ Early } \\
\hline G17 & 73.3 & 73.3 & $73.3 b-f$ & 5 & 4.3 & $4.7 c-f$ \\
\hline G18 & 46.7 & 70 & $58.3 e-j$ & 5.4 & 3.7 & $4.5 c-f$ \\
\hline G19 & 46.7 & 70 & $58.3 e-j$ & 4.5 & 4.0 & 4.3def \\
\hline G20 & 63.3 & 76.7 & $70.0 \mathrm{c}-\mathrm{g}$ & 5.7 & 3.7 & $4.7 c-f$ \\
\hline G21 & 30 & 43.3 & $36.7 \mathrm{k}-\mathrm{o}$ & 5.5 & 4 & $4.8 \mathrm{c}-\mathrm{f}$ \\
\hline G22 & 50 & 70 & $60.0 e-j$ & 5.3 & 4.4 & $4.9 c-f$ \\
\hline G23 & 36.7 & 56.7 & 46.7h-m & 4.7 & 4.6 & $4.6 c-f$ \\
\hline G24 & 23.3 & 40 & 31.71-o & 6.5 & 6 & $6.3 b$ \\
\hline G25 & 23.3 & 56.7 & $40.0 j-n$ & 6 & 4.8 & $5.4 \mathrm{bcd}$ \\
\hline G26 & 16.7 & 23.3 & 20.0no & 6.7 & 4.8 & $5.7 b c$ \\
\hline $\mathrm{G} 27$ & 43.3 & 80 & $61.7 \mathrm{~d}-1$ & 5.1 & 4.2 & $4.6 c-f$ \\
\hline $\mathrm{G} 28$ & 26.7 & 63.3 & 45.0h-m & 5.6 & 4.8 & $5.2 \mathrm{~b}-\mathrm{e}$ \\
\hline G29 (check 2) & 16.7 & 20 & 18.00 & 5.7 & 4.8 & $5.2 \mathrm{~b}-\mathrm{e}$ \\
\hline Group Mean & $42.1 \mathrm{~B}$ & $53.3 \mathrm{~A}$ & & $5.3 \mathrm{~A}$ & $4.6 \mathrm{~A}$ & \\
\hline s.e.d & 14.25 & & 10.54 & & 0.77 & 0.62 \\
\hline I.s.d(0.05) & 28.24 & & & & 1.54 & \\
\hline CV(\%) & 28.7 & & & & 16.5 & \\
\hline
\end{tabular}


Table 3. Morphological growth characters of some maize genotypes under moisture deficit and well watered conditions

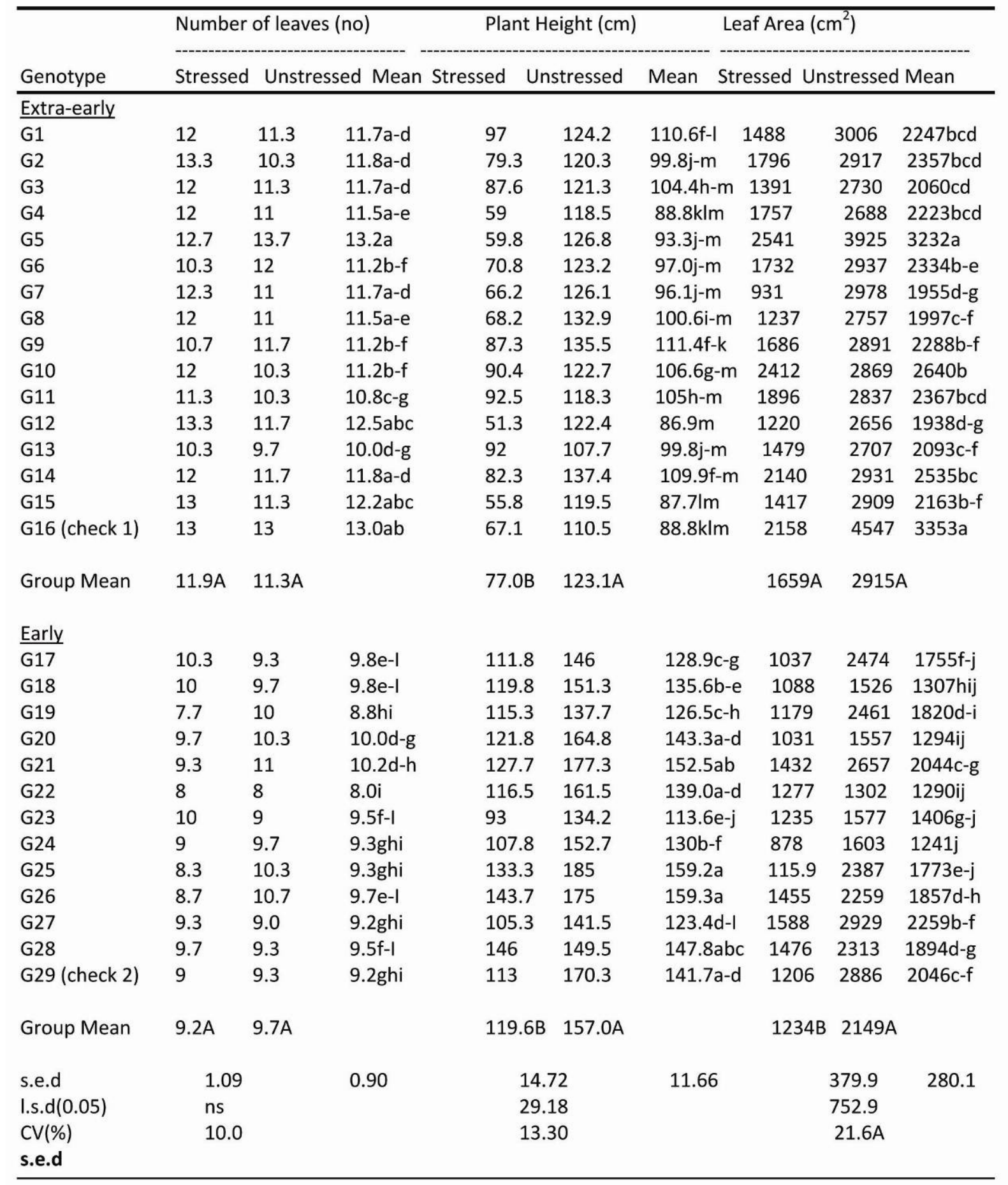


Table 4. Tassel and silk appearances, anthesis and anthesis-silking interval (ASI) of maize genotypes under moisture deficit (STR) and well-watered (WWT) conditions

\begin{tabular}{|c|c|c|c|c|c|c|c|c|c|c|c|c|}
\hline & \multicolumn{3}{|c|}{ Tassel Emergence (DAP) } & \multicolumn{3}{|c|}{ Anthesis (DAP) } & \multicolumn{3}{|c|}{ Silk Emergence (DAP) } & \multirow[b]{2}{*}{ STR } & \multicolumn{2}{|c|}{ ASI (days) } \\
\hline & STR & WWT & Mean & STR & WWT & Mean & STR & WWT & Mean & & WWT & Mean \\
\hline \multicolumn{13}{|c|}{ Extra-early genotype } \\
\hline G1 & 48 & 51 & $49.5 e-h$ & 56 & 54 & $55.0 f-j$ & 62.7 & 59 & $61.0 \mathrm{~b}-\mathrm{e}$ & 6.7 & 5.3 & 6.0a-e \\
\hline G2 & 56.8 & 52.3 & $54.6 a-d$ & 64 & 51 & $57.5 b-h$ & 69 & 54 & $61.5 \mathrm{bcd}$ & 5 & 3 & $4.0 \mathrm{cde}$ \\
\hline G3 & 46.3 & 48.7 & $47.5 \mathrm{gh}$ & 56 & 51.7 & $53.8 \mathrm{~g}-\mathrm{j}$ & 64.7 & 57.3 & $61.0 \mathrm{~b}-\mathrm{e}$ & 9 & 5.7 & 7.3ab \\
\hline G4 & 58.3 & 49.3 & $53.8 \mathrm{a}-\mathrm{f}$ & 62 & 52.3 & $57.2 b-i$ & 66.3 & 57 & $61.7 \mathrm{bc}$ & 4.3 & 4.7 & $4.5 \mathrm{~b}-\mathrm{e}$ \\
\hline G5 & 54.7 & 52 & 53.3a-f & 59.7 & 55 & $57.3 b-h$ & 68.7 & 58.7 & $63.7 a b c$ & 9 & 3.7 & $6.3 a-d$ \\
\hline G6 & 52 & 50 & $51.0 \mathrm{~d}-\mathrm{h}$ & 58.2 & 53.7 & $55.9 d-I$ & 68.7 & 56.7 & $62.7 \mathrm{bc}$ & 10 & 3.0 & $6.5 a b c$ \\
\hline G7 & 50.3 & 50 & $50.2 d-h$ & 56.7 & 54.3 & $55.5 e-j$ & 62 & 58.3 & $60.2 \mathrm{cde}$ & 5.3 & 4 & $4.7 \mathrm{~b}-\mathrm{e}$ \\
\hline G8 & 60.8 & 52.3 & $56.6 a b$ & 64.5 & 55 & $59.8 a-e$ & 71.7 & 58.7 & $65.2 \mathrm{ab}$ & 7.2 & 3.7 & $5.4 b-f$ \\
\hline G9 & 53 & 50 & $51.5 c-h$ & 57.3 & 53.3 & $55.3 e-j$ & 68 & 59 & $63.5 a b c$ & 10.7 & 5.7 & $8.2 a$ \\
\hline G10 & 50 & 48.3 & $49.2 \mathrm{fgh}$ & 55.7 & 51 & 53.3hij & 65 & 54.3 & $59.7 \mathrm{~cd}$ & 9.3 & 3.3 & $6.3 a-d$ \\
\hline G11 & 50 & 45.5 & $47.8 \mathrm{gh}$ & 57.3 & 47.8 & $52.6 \mathrm{ij}$ & 60.7 & 51.7 & $56.2 \mathrm{de}$ & 3.3 & 3 & $3.2 \mathrm{ef}$ \\
\hline G12 & 61.7 & 52.3 & 57.0ab & 64 & 55.7 & $59.8 \mathrm{a}-\mathrm{e}$ & 68.7 & 60.7 & $64.7 a b$ & 4.7 & 5 & $4.8 b-f$ \\
\hline G13 & 45.3 & 48 & $46.7 \mathrm{~h}$ & 51.3 & 50.3 & $50.8 \mathrm{j}$ & 55.7 & 55.7 & $55.7 \mathrm{e}$ & 4.3 & 5.3 & $4.8 b-f$ \\
\hline G14 & 55 & 54 & $54.5 a-f$ & 59.3 & 56.7 & 58.0a-g & 63 & 59.7 & $61.3 b$ & 3.7 & 3 & 3.3def \\
\hline G15 & 56.7 & 52.7 & $54.7 a-d$ & 59.7 & 54.7 & $57.2 \mathrm{~b}-\mathrm{I}$ & 67.8 & 58.3 & 63.0ab & 8 & 3.7 & $5.8 a-e$ \\
\hline G16 & 59.8 & 56.3 & $58.1 \mathrm{a}$ & 63.7 & 58.7 & $61.2 \mathrm{ab}$ & 67.3 & 60.3 & $63.8 \mathrm{ab}$ & 3.7 & 1.7 & $2.71 \mathrm{f}$ \\
\hline GM & $52.9 \mathrm{~A}$ & $50.0 \mathrm{~A}$ & & $58.7 \mathrm{~A}$ & $52.7 \mathrm{~B}$ & & $65.5 \mathrm{~A}$ & $57 \mathrm{~B}$ & & $6.8 \mathrm{~A}$ & $4.3 \mathrm{~B}$ & \\
\hline \multicolumn{13}{|c|}{ Early genotype } \\
\hline G17 & 54.7 & 52.2 & $53.4 a-f$ & 57.7 & 56.7 & $57.2 \mathrm{~b}-\mathrm{g}$ & 63 & 60 & $61.5 \mathrm{bcd}$ & 5.3 & 3.7 & $4.5 b-f$ \\
\hline G18 & 57.7 & 54 & $55.8 \mathrm{abc}$ & 61.7 & 59.3 & $60.5 a b c$ & 64.7 & 62.7 & $63.7 a b c$ & 3.3 & 3.3 & 3.3def \\
\hline G19 & 51.7 & 52.3 & $52.0 \mathrm{~b}-\mathrm{g}$ & 55.3 & 57.7 & $56.5 c-1$ & 59.7 & 61.7 & $60.7 \mathrm{~b}-\mathrm{e}$ & 4.3 & 4 & $4.2 c-f$ \\
\hline G20 & 59 & 55 & 57.0ab & 62 & 60 & 61.0ab & 66.3 & 61.3 & $63.8 \mathrm{abc}$ & 4.3 & 4.7 & $4.5 b-f$ \\
\hline G21 & 57 & 51.7 & 54.3a-e & 61.7 & 56.3 & 59.0a-f & 67 & 59 & 63.0abc & 5.3 & 2.7 & $4.0 c-f$ \\
\hline G22 & 57.7 & 55.7 & 56.7ab & 61.3 & 59.3 & $60.3 a-d$ & 67.8 & 63.3 & $65.6 a b$ & 5.3 & 4 & $4.7 \mathrm{~b}-\mathrm{f}$ \\
\hline G23 & 58.3 & 56.8 & 57.6a & 61.7 & 60.2 & $60.9 a b$ & 64.3 & 64.3 & 64.3abc & 3 & 4.5 & $3.8 \mathrm{c}-\mathrm{f}$ \\
\hline G24 & 58.3 & 56.4 & 57.3a & 63.6 & 60.7 & $62.2 \mathrm{a}$ & 69.6 & 66.7 & $68.2 a$ & 4.7 & 5.7 & $5.2 \mathrm{a}-\mathrm{f}$ \\
\hline G25 & 47.5 & 59.5 & 53.5a-f & 50.1 & 62 & $56.1 \mathrm{c}-1$ & 58.7 & 67.6 & $63.2 \mathrm{abc}$ & 4 & 5.7 & $4.8 b-f$ \\
\hline G26 & 54.9 & 56.9 & 55.9abc & 59 & 60.2 & $59.6 \mathrm{abc}$ & 63.9 & 65.1 & 64.5abc & 3 & 4 & $3.5 c-f$ \\
\hline G27 & 57.3 & 55.3 & 56.3abc & 61 & 59.7 & $60.3 a-d$ & 67 & 64 & 65.5ab & 6 & 4.3 & $5.2 a-f$ \\
\hline G28 & 58.3 & 55.5 & 57.1ab & 62 & 59.5 & $60.8 \mathrm{ab}$ & 66.7 & 62.7 & 64.7abc & 4.7 & 3.7 & $4.2 c-f$ \\
\hline G29 & 57.8 & 55.8 & $56.8 \mathrm{ab}$ & 60.7 & 57.3 & 59.0a-f & 64.6 & 59.3 & $61.9 \mathrm{bc}$ & 4 & 2.7 & 3.3def \\
\hline GM & $55.7 \mathrm{~A}$ & $55.4 \mathrm{~A}$ & & $59.2 \mathrm{~A}$ & $59.3 \mathrm{~A}$ & & $63.9 \mathrm{~A}$ & $63.1 \mathrm{~A}$ & & $4.4 \mathrm{~A}$ & $4.1 \mathrm{~A}$ & \\
\hline s.e.d & \multicolumn{2}{|c|}{3.65} & 2.50 & \multicolumn{2}{|c|}{3.23} & 2.28 & \multicolumn{2}{|l|}{3.56} & 2.67 & 2.04 & & 1.54 \\
\hline I.s.d & \multicolumn{2}{|c|}{7.25} & & \multirow{2}{*}{\multicolumn{2}{|c|}{$\begin{array}{l}6.41 \\
6.9\end{array}$}} & \multirow{2}{*}{\multicolumn{3}{|c|}{$\begin{array}{l}1.07 \\
6.5\end{array}$}} & \multicolumn{4}{|c|}{4.05} \\
\hline CV(\%) & \multicolumn{2}{|l|}{8.5} & 6.9 & & & & & & \multicolumn{4}{|c|}{18.5} \\
\hline
\end{tabular}


Table 5. Net assimilation rate, crop growth rate and relative growth rate of maize genotype under moisture deficit (STR) and well-watered (WWT) conditions

\begin{tabular}{|c|c|c|c|c|c|c|c|c|c|}
\hline & \multicolumn{3}{|c|}{$\begin{array}{l}\text { Net assimilation rate } \\
\qquad\left(\mathrm{g} \mathrm{m}^{-2} \mathrm{~d}^{-1}\right)\end{array}$} & \multicolumn{3}{|c|}{$\begin{array}{r}\text { Crop growth rate } \\
\qquad\left(\mathrm{g} \mathrm{g}^{-1} \mathrm{~d}^{-1}\right)\end{array}$} & \multicolumn{3}{|c|}{ Relative growth rate } \\
\hline & STR & WWT & Mean & STR & WWT & Mean & STR & WWT & Mean \\
\hline \multicolumn{10}{|c|}{ Extra-early genotype } \\
\hline G1 & 10.9 & 8 & $9.5 \mathrm{cde}$ & 0.27 & 1.75 & $1.01 \mathrm{a}$ & 0.077 & 0.136 & 0.107 \\
\hline G2 & 14 & 51.4 & $32.7 a$ & 0.43 & 1.08 & $0.76 a-e$ & 0.179 & 0.194 & 0.186 \\
\hline G3 & 3.9 & 36.6 & $20.2 a-d$ & 0.39 & 1.62 & $1.01 \mathrm{a}$ & 0.010 & 0.128 & 0.069 \\
\hline G4 & 8.3 & 6.5 & 7.4de & 0.23 & 0.69 & $0.46 \mathrm{cde}$ & 0.104 & 0.076 & 0.090 \\
\hline G5 & 5.4 & 16 & 10.7cde & 0.37 & 1.17 & $0.77 a-d$ & 0.135 & 0.128 & 0.131 \\
\hline G6 & 5.8 & 11.6 & $8.7 \mathrm{cde}$ & 0.07 & 1.36 & 0.64a-e & 0.091 & 0.174 & 0.133 \\
\hline G7 & 7.5 & 9.4 & $8.5 \mathrm{cde}$ & 0.09 & 1.07 & $0.58 a-e$ & 0.065 & 0.145 & 0.105 \\
\hline G8 & 14.3 & 8.7 & $11.5 \mathrm{cde}$ & 0.17 & 0.83 & $0.50 \mathrm{cde}$ & 0.139 & 0.103 & 0.121 \\
\hline G9 & 12.5 & 8.5 & $10.5 \mathrm{cde}$ & 0.17 & 1.02 & 0.60a-e & 0.076 & 0.106 & 0.091 \\
\hline G10 & 17.6 & 41 & $29.3 a b$ & 0.50 & 0.96 & $0.73 a-d$ & 0.125 & 0.128 & 0.126 \\
\hline G11 & 12.1 & 8.5 & $10.3 \mathrm{~cd}-\mathrm{e}$ & 0.23 & 1.35 & $0.79 a-d$ & 0.075 & 0.124 & 0.099 \\
\hline G12 & 5.9 & 8.7 & 7.3de & 0.23 & 0.99 & 0.61a-e & 0.348 & 0.124 & 0.236 \\
\hline G13 & 4.9 & 27.8 & $16.3 b-e$ & 0.51 & 1.34 & $0.93 a b$ & 0.087 & 0.150 & 0.119 \\
\hline G14 & 9.9 & 11.2 & $10.5 \mathrm{cde}$ & 0.31 & 1.42 & $0.86 a b c$ & 0.09 & 0.142 & 0.110 \\
\hline G15 & 3.3 & 9.3 & $6.3 e$ & 0.12 & 1.39 & $0.75 a-d$ & 0.057 & 0.113 & 0.085 \\
\hline G16 & 11.9 & 28.4 & 20.1a-d & 0.41 & 1.32 & $0.87 a b c$ & 0.178 & 0.89 & 0.184 \\
\hline GM & $9.3 \mathrm{~A}$ & $18.2 \mathrm{~A}$ & & $0.27 \mathrm{~B}$ & $1.17 \mathrm{~A}$ & & $0.116 \mathrm{~A}$ & $0.132 \mathrm{~A}$ & \\
\hline \multicolumn{10}{|c|}{ Early genotype } \\
\hline G17 & 16.6 & 12.7 & 14.7bcd & 0.51 & 1.47 & $0.99 a b$ & 0.123 & 0.162 & 0.142 \\
\hline G18 & 12.1 & 8.7 & $10.4 \mathrm{~cd}$ & 0.56 & 0.34 & $0.45 c d$ & 0.129 & 0.124 & 0.126 \\
\hline G19 & 10.4 & 7.7 & $9.1 \mathrm{~cd}$ & 0.55 & 0.96 & $0.75 a-d$ & 0.140 & 0.110 & 0.125 \\
\hline G20 & 5.2 & 9.7 & $7.4 d$ & 0.23 & 0.93 & $0.58 a-e$ & 0.327 & 0.020 & 0.173 \\
\hline G21 & 5.8 & 9.7 & $7.7 d$ & 0.36 & 0.39 & $0.37 \mathrm{de}$ & 0.107 & 0.127 & 0.117 \\
\hline G22 & 9.5 & 13.6 & $11.6 \mathrm{c}$ & 0.58 & 0.92 & $0.75 a-d$ & 0.125 & 0.103 & 0.114 \\
\hline G23 & 8.8 & 8.8 & $8.8 \mathrm{cde}$ & 0.49 & 0.47 & $0.48 \mathrm{cde}$ & 0.126 & 0.075 & 0.101 \\
\hline G24 & 13 & 7.3 & 10.1cde & 0.10 & 1.02 & $0.56 \mathrm{~b}-\mathrm{e}$ & 0.137 & 0.127 & 0.132 \\
\hline G25 & 32 & 11 & $21.5 \mathrm{abc}$ & 0.34 & 0.11 & $0.23 \mathrm{e}$ & 0.122 & 0.184 & 0.153 \\
\hline G26 & 15.7 & 26.7 & $21.2 \mathrm{abc}$ & 0.68 & 1.22 & $0.95 a b$ & 0.140 & 0.152 & 0.146 \\
\hline G27 & 7.8 & 9.8 & $8.8 \mathrm{cde}$ & 0.47 & 1.42 & $0.94 a b$ & 0.130 & 0.132 & 0.131 \\
\hline G28 & 8.3 & 7.5 & 7.9de & 0.52 & 1.23 & $0.88 \mathrm{abc}$ & 0.131 & 0.125 & 0.128 \\
\hline G29 & 7.2 & 11.9 & 9.5cde & 0.49 & 1.21 & $0.85 a b c$ & 0.123 & 0.124 & 0.123 \\
\hline GM & $11.7 \mathrm{~A}$ & 11.2 & & $0.49 B$ & $0.89 \mathrm{~A}$ & & $0.141 \mathrm{~A}$ & $0.118 \mathrm{~A}$ & \\
\hline s.e.d & \multicolumn{2}{|c|}{10.17} & 6.57 & \multicolumn{2}{|c|}{0.311} & 0.218 & \multicolumn{2}{|c|}{0.0742} & 0.0542 \\
\hline I.s.d & \multicolumn{2}{|c|}{20.19} & & \multicolumn{2}{|c|}{0.619} & & \multicolumn{2}{|c|}{ ns } & \\
\hline CV(\%) & \multicolumn{2}{|c|}{63.4} & & \multicolumn{2}{|c|}{54.1} & & \multicolumn{2}{|r|}{68.6} & \\
\hline
\end{tabular}


Table 6. Leaf area ratio and leaf area index of maize genotype under moisture deficit (STR) and well-watered (WWT) conditions

\begin{tabular}{|c|c|c|c|c|c|c|c|}
\hline \multirow[t]{2}{*}{ Treatment } & \multirow[b]{2}{*}{ STR } & \multicolumn{3}{|c|}{ Leaf area ratio (LAR) } & \multicolumn{2}{|c|}{ Leaf area index (LAI) } & \multirow[b]{2}{*}{ Mean } \\
\hline & & & WWT & Mean & STR & WWT & \\
\hline \multicolumn{8}{|c|}{ Extra-early genotype } \\
\hline G1 & 151.2 & & 138.4 & $144.8 \mathrm{~cd}$ & 2.48 & 5.01 & $3.74 c-g$ \\
\hline G2 & 208.2 & & 52.4 & $130.3 d$ & 2.99 & 4.86 & $3.93 \mathrm{cde}$ \\
\hline G3 & 245.6 & & 123.7 & 184.7abc & 2.32 & 4.55 & $3.44 c-g$ \\
\hline G4 & 169.6 & & 165.1 & $167.4 a-d$ & 2.93 & 4.48 & $3.71 \mathrm{c}-\mathrm{g}$ \\
\hline G5 & 211.8 & & 143.2 & $177.5 a-d$ & 4.23 & 6.54 & $5.39 a b$ \\
\hline G6 & 174 & & 162.7 & $168.4 a-d$ & 2.96 & 4.89 & $3.93 \mathrm{cde}$ \\
\hline G7 & 191.7 & & 177.6 & $184.6 a b c$ & 1.55 & 4.97 & $3.26 \mathrm{~d}-\mathrm{i}$ \\
\hline G8 & 176.2 & & 147.8 & $162.0 a-d$ & 2.06 & 4.60 & $3.33 d-i$ \\
\hline G9 & 234.7 & & 141.1 & 187.9abc & 2.81 & 4.82 & $3.82 c-f$ \\
\hline G10 & 141.7 & & 156.4 & 149.1bcd & 4.02 & 4.78 & $4.40 \mathrm{bc}$ \\
\hline G11 & 171.6 & & 153.6 & $162.6 a-d$ & 3.16 & 4.99 & $4.08 \mathrm{~cd}$ \\
\hline G12 & 189.6 & & 167 & 178.3a-d & 2.03 & 4.43 & $3.23 e-j$ \\
\hline G13 & 189.8 & & 124.8 & $157.3 \mathrm{bcd}$ & 2.47 & 4.51 & $3.49 c-h$ \\
\hline G14 & 163.5 & & 147.4 & $155.4 \mathrm{bcd}$ & 3.57 & 4.88 & $4.23 c d$ \\
\hline G15 & 213.1 & & 141.1 & 177.1a-d & 2.36 & 4.85 & $3.61 c-g$ \\
\hline G16 (check 1) & 186.8 & & 117.3 & $152.0 \mathrm{bcd}$ & 3.60 & 7.58 & $5.59 a$ \\
\hline Group Mean & 188.9A & & $142.6 \mathrm{~A}$ & & $2.77 \mathrm{~B}$ & $4.88 \mathrm{~A}$ & \\
\hline \multicolumn{8}{|l|}{ Early genotype } \\
\hline G17 & 148.9 & & 161 & $154.9 \mathrm{bcd}$ & 1.73 & 4.03 & $2.88 f-k$ \\
\hline G18 & 182.2 & & 104.6 & $143.4 \mathrm{~cd}$ & 1.81 & 2.54 & $2.18 \mathrm{k}$ \\
\hline G19 & 146.9 & & 159.2 & $153.0 \mathrm{bcd}$ & 1.97 & 4.10 & $3.03 e-k$ \\
\hline G20 & 248 & & 160.2 & 204.3ab & 1.72 & 2.68 & $2.20 \mathrm{k}$ \\
\hline G21 & 187.5 & & 146.5 & 167.0a-d & 2.39 & 4.43 & $3.41 c-h$ \\
\hline G22 & 148.2 & & 95.6 & $121.9 d$ & 2.32 & 2.17 & $2.24 \mathrm{jk}$ \\
\hline G23 & 167.6 & & 159.6 & 163.6a-d & 2.06 & 2.63 & $2.34 \mathrm{ijk}$ \\
\hline G24 & 194.7 & & 124.9 & $159.8 a-d$ & 1.28 & 3.11 & $2.20 \mathrm{k}$ \\
\hline G25 & 176.4 & & 252.7 & $214.5 a$ & 1.52 & 3.87 & $2.69 \mathrm{~h}-\mathrm{k}$ \\
\hline G26 & 182.1 & & 138.5 & $160.3 a-d$ & 2.61 & 2.96 & $2.78 \mathrm{~g}-\mathrm{k}$ \\
\hline $\mathrm{G} 27$ & 170.5 & & 149.3 & $159.9 a-d$ & 2.64 & 4.88 & $3.76 c-g$ \\
\hline G28 & 192.4 & & 121 & $156.7 \mathrm{bcd}$ & 2.46 & 4.25 & $3.35 e-i$ \\
\hline G29 (check 2) & 143.8 & & 103.4 & $123.6 \mathrm{~d}$ & 3.16 & 5.03 & $4.10 \mathrm{~cd}$ \\
\hline Group Mean & 176.7A & & 143.0A & & $2.15 B$ & $3.5 \mathrm{~A}$ & \\
\hline s.e.d & & 35.81 & & 28.09 & & & 0.495 \\
\hline I.s.d & & 71.14 & & & & & \\
\hline CV(\%) & & 23.6 & & & & & \\
\hline
\end{tabular}


Table 7. Harvest index, shelling percentage and number of kernels of maize genotypes under moisture deficit (STR) and well-watered (WWT) conditions

\begin{tabular}{|c|c|c|c|c|c|c|c|c|c|}
\hline \multirow[b]{2}{*}{ Genotype } & \multicolumn{3}{|c|}{ Harvest index } & \multicolumn{3}{|c|}{ Shelling percentage } & \multicolumn{3}{|c|}{ Number of kernels/cob } \\
\hline & STR & WWT & Mean & STR & WWT & Mean & STR & WWT & Mean \\
\hline \multicolumn{10}{|l|}{ Extra-early } \\
\hline$\overline{\mathrm{G} 1}$ & 0.19 & 0.36 & $0.28 \mathrm{efg}$ & 32.3 & 64.7 & 48.5ef & 117.3 & 224.0 & $180.7 \mathrm{bcd}$ \\
\hline G2 & 0.50 & 0.48 & $0.49 a$ & 62.0 & 83.0 & $72.5 a-d$ & 114.6 & 336.0 & 225.3a-d \\
\hline G3 & 0.23 & 0.35 & $0.29 \mathrm{~d}-\mathrm{g}$ & 59.0 & 77.0 & 68.0a-e & 144.0 & 308.0 & 226.0a-d \\
\hline G4 & 0.29 & 0.33 & $0.32 \mathrm{~d}-\mathrm{g}$ & 68.3 & 67.0 & 67.7a-e & 202.7 & 149.8 & $176.3 \mathrm{bcd}$ \\
\hline G5 & 0.22 & 0.38 & $0.30 \mathrm{~d}-\mathrm{g}$ & 49.3 & 70.0 & $59.7 c-f$ & 166.0 & 297.0 & 231.5abc \\
\hline G6 & 0.34 & 0.47 & $0.41 \mathrm{a}-\mathrm{e}$ & 54.0 & 74.0 & 64.0a-e & 191.7 & 389.3 & $290.5 a b c$ \\
\hline G7 & 0.40 & 0.44 & $0.42 a-d$ & 72.3 & 82.0 & $77.2 \mathrm{ab}$ & 170.3 & 364.0 & $267.2 \mathrm{abc}$ \\
\hline G8 & 0.24 & 0.53 & $0.39 a-f$ & 58.7 & 79.7 & $69.2 a-d$ & 122.0 & 334.3 & 228.1a-d \\
\hline G9 & 0.46 & 0.46 & $0.46 a b c$ & 66.3 & 78.3 & $72.3 a-d$ & 283.8 & 255.3 & $269.6 a b c$ \\
\hline G10 & 0.35 & 0.49 & $0.42 a-d$ & 55.0 & 80.0 & $67.5 a-d$ & 243.7 & 408.7 & $326.2 a$ \\
\hline G11 & 0.40 & 0.54 & $0.47 a b$ & 66.0 & 82.0 & $74.0 a-d$ & 234.0 & 322.3 & $278.2 \mathrm{abc}$ \\
\hline G12 & 0.19 & 0.53 & $0.36 a-f$ & 51.0 & 84.3 & $67.7 a-d$ & 146.3 & 344.3 & $245.3 a b c$ \\
\hline G13 & 0.22 & 0.52 & $0.37 a-f$ & 63.3 & 81.0 & $72.2 a-d$ & 109.0 & 282.3 & $195 a-d$ \\
\hline G14 & 0.23 & 0.48 & $0.36 a-f$ & 44.3 & 78.3 & $61.3 a-f$ & 207.0 & 391.7 & 299.3ab \\
\hline G15 & 0.24 & 0.45 & $0.34 \mathrm{~b}-\mathrm{g}$ & 59.3 & 78.0 & $68.7 a-d$ & 294.3 & 283.0 & 288.7abc \\
\hline G16 (chk1) & 0.16 & 0.44 & $0.30 \mathrm{~d}-\mathrm{g}$ & 45.0 & 65.0 & 55.0c-f & 239.3 & 330.3 & 282.3abc \\
\hline Group Mean & $0.31 \mathrm{~B}$ & $0.46 \mathrm{~A}$ & & $58.3 \mathrm{~B}$ & $77.2 \mathrm{~A}$ & & 172.7B & $310 \mathrm{~A}$ & \\
\hline \multicolumn{10}{|l|}{ Early } \\
\hline$\overline{\mathrm{G} 17}$ & 0.35 & 0.40 & $0.37 a-f$ & 68.1 & 71.8 & 69.9a-e & 162.3 & 153.3 & $157.8 \mathrm{~cd}$ \\
\hline G18 & 0.22 & 0.343 & $0.28 \mathrm{efg}$ & 51.6 & 68.5 & $60.0 b-f$ & 200.0 & 221.7 & $210.8 a-d$ \\
\hline G19 & 0.34 & 0.43 & $0.39 a-f$ & 65.0 & 83.9 & 74.4abc & 162.3 & 288.7 & 225.5a-d \\
\hline G20 & 0.11 & 0.31 & $0.21 \mathrm{~g}$ & 35.0 & 57.7 & $46.3 f$ & 46.0 & 147.7 & $96.8 d$ \\
\hline G21 & 0.33 & 0.28 & $0.30 \mathrm{~d}-\mathrm{g}$ & 66.4 & 57.2 & $61.8 \mathrm{a}-\mathrm{f}$ & 201.7 & 343.0 & 272.3abc \\
\hline G22 & 0.32 & 0.36 & $0.34 \mathrm{~b}-\mathrm{g}$ & 53.8 & 76.0 & $65.2 \mathrm{a}-\mathrm{f}$ & 131.2 & 243.3 & $187 \mathrm{bcd}$ \\
\hline G23 & 0.21 & 0.37 & $0.29 \mathrm{~d}-\mathrm{g}$ & 72.4 & 89.8 & $81.1 a$ & 171.7 & 331.1 & 251.4abc \\
\hline G24 & 0.21 & 0.32 & $0.26 \mathrm{fg}$ & 47.5 & 70.2 & $58.9 c-f$ & 152.7 & 381.3 & 267.0ab \\
\hline G25 & 0.32 & 0.31 & $0.32 \mathrm{~d}-\mathrm{g}$ & 60.3 & 60.9 & $60.6 b-f$ & 189.3 & 287.7 & $238.5 a b$ \\
\hline G26 & 0.25 & 0.28 & $0.26 f g$ & 55.7 & 55.1 & 54.4def & 159.7 & 267.7 & 213.7abc \\
\hline G27 & 0.30 & 0.36 & $0.33 c-g$ & 58.5 & 77.1 & 67.8a-e & 183.0 & 233.3 & 208.2abc \\
\hline G28 & 0.39 & 0.35 & $0.37 a-f$ & 40.2 & 62.7 & 51.5ef & 158.7 & 214.7 & $186.7 \mathrm{bc}$ \\
\hline G29(chk2) & 0.12 & 0.41 & $0.27 f g$ & 31.7 & 59.2 & $45.6 f$ & 186.0 & 251.3 & 221.7abc \\
\hline Group Mean & $0.27 \mathrm{~B}$ & $0.35 \mathrm{~A}$ & & $54.3 B$ & $68.4 \mathrm{~A}$ & & $161.9 \mathrm{~B}$ & 259.3 & \\
\hline s.e.d & \multicolumn{2}{|c|}{0.089} & 0.068 & \multicolumn{2}{|c|}{13.59} & 9.95 & \multirow{2}{*}{\multicolumn{2}{|c|}{$\begin{array}{l}81.81 \\
162.37\end{array}$}} & 68.11 \\
\hline I.s.d (0.05) & \multicolumn{2}{|c|}{0.177} & & \multicolumn{2}{|c|}{26.94} & & & & \\
\hline CV (\%) & \multicolumn{2}{|c|}{29.2} & & \multicolumn{2}{|c|}{25.0} & & \multicolumn{2}{|r|}{33.7} & \\
\hline
\end{tabular}


Table 8. Grain yields under soil moisture deficit (Ys), normal soil moisture (Yp), yield reduction percent due to moisture deficit (PRED) and Drought Susceptibility Index (DSI) of maize genotypes of two maturity groups

\begin{tabular}{|c|c|c|c|c|c|}
\hline \multirow[b]{2}{*}{ Genotype } & \multicolumn{3}{|c|}{ Grain yield (g plant ${ }^{-1}$ ) } & \multirow[b]{2}{*}{ PRED (\%) } & \multirow[b]{2}{*}{ DSI } \\
\hline & Ys & $Y p$ & Mean & & \\
\hline \multicolumn{6}{|l|}{ Extra-early } \\
\hline $\mathrm{G} 1$ & $14.0 \mathrm{c}$ & $43.5 d$ & $28.8 c$ & $70.4 \mathrm{ab}$ & $1.41 \mathrm{ab}$ \\
\hline G2 & 47.1abc & $91.2 \mathrm{abc}$ & $60.7 \mathrm{ab}$ & $68.5 \mathrm{ab}$ & $1.37 \mathrm{abc}$ \\
\hline G3 & $21.0 \mathrm{abc}$ & $84.4 a-d$ & 52.7abc & $75.0 \mathrm{ab}$ & $1.50 \mathrm{ab}$ \\
\hline G4 & 33.0abc & $54.2 a-d$ & 43.6abc & $39.8 b-e$ & $0.79 b-e$ \\
\hline G5 & $34.0 \mathrm{abc}$ & $83.2 a-d$ & $58.6 a b c$ & $65.7 \mathrm{abc}$ & $1.31 \mathrm{a}-\mathrm{d}$ \\
\hline G6 & $21.5 \mathrm{abc}$ & $65.5 a-d$ & $43.5 a b c$ & $66.1 \mathrm{abc}$ & $1.32 \mathrm{a}-\mathrm{d}$ \\
\hline G7 & $35.1 \mathrm{abc}$ & $76.7 a-d$ & 55.9abc & $52.7 a-d$ & 1.06a-e \\
\hline G8 & $12.7 a b c$ & $91.8 \mathrm{a}$ & 52.9abc & $81.3 a$ & $1.63 a$ \\
\hline G9 & $44.8 \mathrm{abc}$ & $64.2 a-d$ & 53.0abc & 61.0a-d & 1.22a-e \\
\hline G10 & $52.3 a$ & $95.3 a b$ & $73.8 \mathrm{a}$ & 49.0a-e & $0.98 a-e$ \\
\hline G11 & 33.7abc & $90.0 \mathrm{abc}$ & $61.8 \mathrm{ab}$ & $62.2 a-d$ & $1.24 a-d$ \\
\hline G12 & $24.4 a b c$ & $66.6 a-d$ & $45.5 a b c$ & $65.7 a b c$ & $1.31 a-d$ \\
\hline G13 & $21.3 a b c$ & $47.4 \mathrm{~cd}$ & $34.3 b c$ & $56.5 a-d$ & 1.13a-e \\
\hline G14 & $29.4 a b c$ & $75.1 a-d$ & $52.3 a b c$ & $60.8 a-d$ & 1.21a-e \\
\hline G15 & $32.3 a b c$ & $66.0 a-d$ & $49.1 \mathrm{abc}$ & 48.7a-e & $0.97 a-e$ \\
\hline G16 (chk1) & $18.3 a b c$ & $80.0 \mathrm{abc}$ & 48.7abc & 79.6ab & $1.58 a b$ \\
\hline Group Mean & $29.6 C$ & $72.7 \mathrm{~A}$ & 51 & 62.7 & 1.15 \\
\hline \multicolumn{6}{|l|}{ Early } \\
\hline G17 & $36.2 a b c$ & $42.2 \mathrm{~d}$ & $39.2 b c$ & 47.8a-e & 1.03a-e \\
\hline G18 & $33.7 a b c$ & $56.4 a-d$ & $45.1 \mathrm{abc}$ & $44.2 \mathrm{~b}-\mathrm{e}$ & $0.88 \mathrm{~b}-\mathrm{e}$ \\
\hline G19 & $40.1 \mathrm{abc}$ & $54.3 a-d$ & $47.2 \mathrm{abc}$ & $42.2 \mathrm{~b}-\mathrm{e}$ & $0.84 b-e$ \\
\hline G20 & $18.4 b c$ & $50.4 \mathrm{~cd}$ & $34.4 b c$ & $50.2 a-d$ & 1.00a-e \\
\hline G21 & $47.2 \mathrm{abc}$ & $78.2 a-d$ & $62.7 \mathrm{ab}$ & 40.0b-e & $0.80 \mathrm{~b}-\mathrm{e}$ \\
\hline G22 & $40.1 \mathrm{abc}$ & $51.0 \mathrm{~cd}$ & $45.6 a b c$ & 20.5 e & $0.41 \mathrm{e}$ \\
\hline G23 & $41.8 \mathrm{abc}$ & $57.5 a-d$ & $52.0 \mathrm{abc}$ & $27.0 \mathrm{e}$ & $0.54 \mathrm{cde}$ \\
\hline G24 & $36.0 \mathrm{abc}$ & $71.6 a-d$ & $53.8 \mathrm{abc}$ & 53.3a-g & 1.06a-e \\
\hline G25 & $50.8 \mathrm{ab}$ & $74.8 \mathrm{a}-\mathrm{d}$ & $62.8 \mathrm{ab}$ & $30.1 \mathrm{de}$ & $0.60 \mathrm{de}$ \\
\hline G26 & 35.1abc & $62.0 a-d$ & $48.6 a b c$ & 46.9a-e & 0.94a-e \\
\hline G27 & $35.2 a b c$ & $52.1 \mathrm{bcd}$ & 43.7abc & $32.0 \mathrm{cde}$ & $0.64 \mathrm{cde}$ \\
\hline G28 & $30.7 a b c$ & $50.0 \mathrm{~cd}$ & $40.4 b c$ & $40.5 b-e$ & $0.81 b-e$ \\
\hline G29 (chk2) & $21.6 a b c$ & 64.9a-d & 43.3abc & 46.9a-e & 0.93a-e \\
\hline Group Mean & $35.9 \mathrm{C}$ & $59.3 \mathrm{~B}$ & 47.6 & 40.1 & 0.81 \\
\hline s.e.d & 17.29 & 21.9 & 15.29 & 16.9 & 0.348 \\
\hline CV(\%) & 61.7 & 39.8 & 37.9 & 40.7 & 40.4 \\
\hline
\end{tabular}




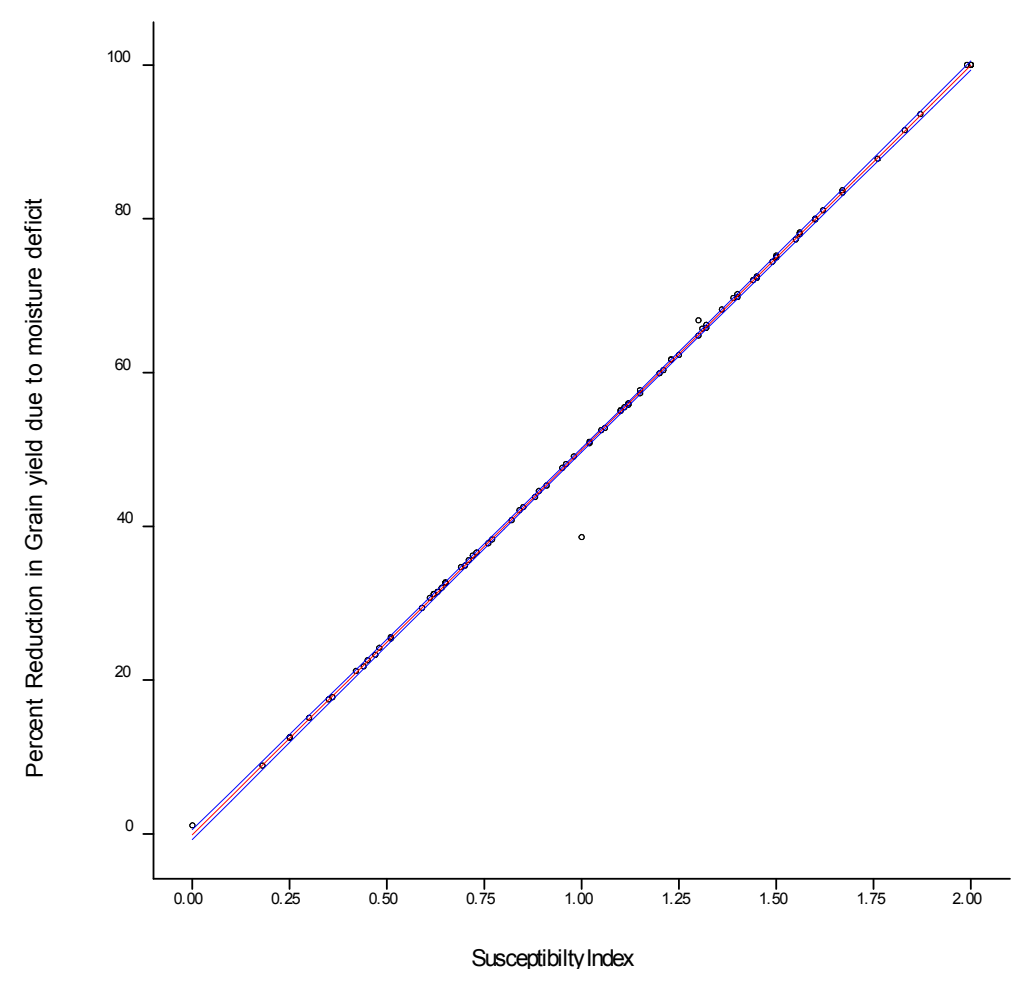

Figure 1a. Relationship between percent reduction in grain yield due to soil moisture deficit and drought susceptibility index in maize

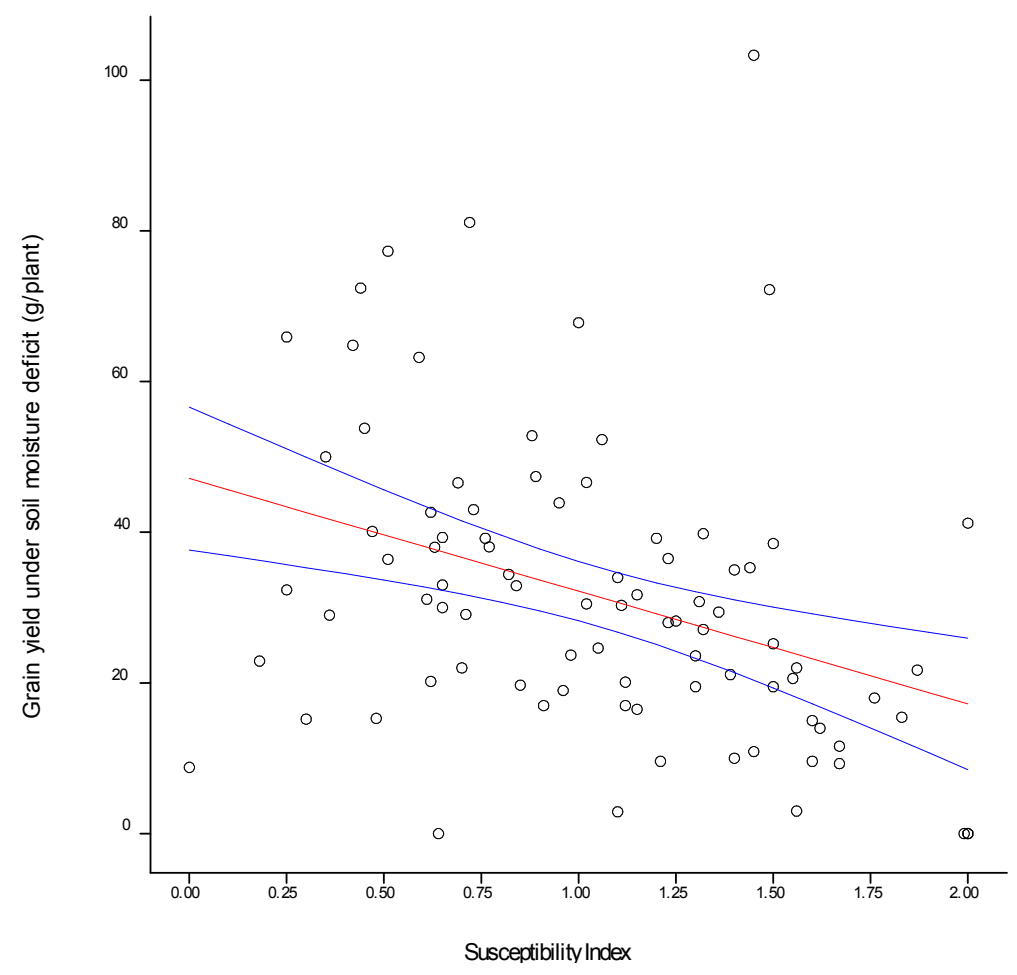

Figure 1b. Relationship between grain yield under stress and drought susceptibility index in maize 